\title{
Kemampuan Representasi Matematis Siswa dalam Memecahkan Masalah Relasi dan Fungsi Kelas VIII SMP
}

\author{
Dini Sofiatul Iffa ${ }^{1, \text { a) }}$, Sri Subarinah ${ }^{2, \text { b) }}$, Baidowi $^{3, \text { c) }}$, Sripatmi $^{4, d)}$ \\ ${ }^{1}$ Mahasiswa Universitas Mataram, Mataram, Nusa Tenggara Barat \\ ${ }^{234}$ Universitas Mataram, Mataram, Nusa Tenggara Barat \\ Email penulis: ${ }^{\text {a) }}$ dinisofiatuliff4@gmail.com, ${ }^{\text {b) }}$ s.subarinah@gmail.com, ${ }^{c}$ baidowiunram@gmail.com, \\ d)sripadmi@unram.ac.id
}

\begin{abstract}
This study aimed to knowing and describe students' mathematical representation skills in solving relational and function problems for class VIII in academic year 2021/2022. The research method used was descriptive research with a qualitative approach. The instruments used were mathematical representation ability tests and interview. The research subjects were students VIII C with 30 students who were given a mathematical representation ability test grouped into high, medium, and low categories based on their mathematical ability. From each category, 2 students were selected to be interviewed further. In general, from the test results, students with high mathematical representation abilities have been able to achieve indicators of mathematical representation abilities with an achievement percentage of $82.63 \%$ which is very good. Students with moderate mathematical representation skills with an achievement percentage of $51.26 \%$, which is sufficient. and students with low mathematical representation skills with an achievement percentage of $25.95 \%$, which is less. From the results of interviews, students with high mathematical mathematical representation abilities were able to explain the answers to the test results very well. Students with moderate mathematical representation skills are quite able to explain their answers well. Students with low mathematical representation ability are able to explain the answer but the explanation given is less detailed.
\end{abstract}

Keywords: Mathematical Representation Ability, Problem Solving, Relation and Function

\begin{abstract}
Abstrak
Penelitian ini bertujuan untuk mengetahui dan mendeskripsikan kemampuan representasi matematis siswa dalam memecahkan masalah relasi dan fungsi kelas VIII tahun ajaran 2021/2022. Metode penelitian yang digunakan adalah penelitian deskriptif dengan pendekatan kualitatif. Instrumen yang digunakan dalam penelitian ini adalah tes kemampuan representasi matematis dan wawancara. Subjek penelitiannya yaitu siswa kelas VIII C dengan 30 siswa yang diberikan tes kemampuan representasi matematis dikategorikan ke dalam kemampuan representasi matematis tinggi, sedang, dan rendah. secara umum dari hasil tes, siswa dengan kemampuan representasi matematis tinggi telah mampu mencapai indikator kemampuan representasi matematis dengan persentase ketercapaian yaitu $82,63 \%$ yaitu sangat baik. Siswa dengan kemampuan representasi matematis sedang dengan persentase ketercapaian yaitu 51,26\% yaitu cukup. dan siswa dengan kemampuan representasi matematis rendah dengan persentase ketercapaian yaitu $25,95 \%$ yaitu kurang. Dari hasil wawancara, siswa dengan kemampuan representasi matematis matematis tinggi mampu menjelaskan jawaban dari hasil tes dengan sangat baik. Siswa dengan kemampuan representasi matematis sedang cukup mampu menjelaskan jawabannya dengan baik. Siswa dengan kemampuan representasi matematis rendah mampu menjelaskan jawabannya namun penjelasan yang disampaikan kurang detail.
\end{abstract}

Kata kunci: Kemampuan Representasi Matematis, Pemecahan Masalah, Relasi dan Fungsi

Copyright (c) 2022 Iffa, Subarinah, Baidowi, Sripatmi

$\triangle$ Corresponding author:

Email Address: dinisofiatuliff4@gmail.com

Received 19 Januari 2022, Accepted 23 Februari 2022, Published 24 Februari 2022

https://doi.org/10.21009/jrpmj.v4i1.23021

\section{PENDAHULUAN}

Pendidikan merupakan aspek yang sangat penting bagi diri manusia sebagai bekal dalam menjalankan kehidupan kedepannya. Dalam Peraturan Menteri Pendidikan Nasional Republik 
Indonesia Nomor 20 tahun 2006 tentang Standar isi salah satunya yaitu mengatakan dalam pembelajaran matematika bertujuan agar siswa memiliki kemampuan Mengkomunikasikan gagasan dengan simbol, tabel, diagram, atau media lain untuk memperjelas keadaan atau masalah (Depdiknas, 2006).

National Council of Teacher of Mathematics menyebutkan lima standar kompetensi dalam pembelajaran matematika yaitu kemampuan pemecahan masalah, kemampuan Komunikasi, kemampuan koneksi, kemampuan penalaran, dan kemampuan representasi (NCTM, 2000). Menurut Huda, Musdi, dan Nari (2019) representasi matematis adalah tafsiran dari pemahaman siswa berupa ide-ide yang terkonstruksi di dalam pikiran terhadap suatu masalah yang dikomunikasikan dalam bentuk fisik berupa istilah-istilah, gambar, tulisan, benda konkrit atau simbol untuk memudahkan penemuan solusi dari suatu permasalahan. Kemampuan representasi matematis memiliki peran penting dalam membantu siswa memecahkan masalah matematika hal ini sejalan dengan dengan hasil penelitian Hwang, Chen, Dung, dan Yang (2007) menyimpulkan bahwa kemampuan representasi merupakan kunci bagi siswa untuk dapat memecahkan permasalahan dengan baik. Dari hasil penelitian Kalathil dan Sherin (2000) bahwa kemampuan representasi matematis sebagai informasi tentang pola dan kecenderungan (trend) diantara siswa. Jones (dalam Sabirin, 2014) mengungkapkan alasan yang mendasari representasi sebagai komponen standar proses salah satunya yaitu kelancaran dalam melakukan translasi di antara berbagai bentuk representasi berbeda, merupakan kemampuan mendasar yang perlu dimiliki siswa untuk membangun konsep dan berpikir matematis.

Berdasarkan hasil wawancara dengan salah satu guru SMPN 12 Mataram bahwa siswa masih kurang dalam menyajikan diagram atau gambar dan masih kurang memahami konsep. Hal ini ditunjukkan dengan siswa masih salah dalam menggambar diagram kartesius dengan benar. Selain itu juga siswa masih kesulitan dalam menuliskan himpunan pasangan berurutan. Hal ini disebabkan rendahnya minat belajar siswa, terlebih dimasa pandemi ini siswa lebih sering belajar secara daring sehingga proses pembelajaran menjadi kurang maksimal. Prestasi belajar siswa rendah disebabkan oleh keaktifan siswa dalam mengikuti pembelajaran masih kurang, siswa jarang mengumpulkan tugas yang diberikan guru secara online dan jarang mengajukan pertanyaan meskipun guru sering memberikan kesempatan kepada siswa untuk bertanya tentang hal - hal yang belum dipahami.

Berdasarkan uraian diatas tujuan penelitian ini adalah untuk mengetahui dan mendeskripsikan kemampuan representasi matematis (visual, simbolik, verbal) yang ditinjau dari kemampuan matematika siswa dalam memecahkan masalah relasi dan fungsi kelas VIII Tahun ajaran 2021/2022.

\section{METODE}

Jenis penelitian yang digunakan pada penelitian ini adalah penelitian deskriptif dengan pendekatan kualitatif. Seperti yang dijelaskan oleh Sugiyono (2013), peneliti bermaksud memaparkan dan menginterpretasikan keadaan objek sebenarnya. Penelitian ini bertujuan untuk mendeskripsikan atau memaparkan kemampuan representasi matematis siswa dalam memecahkan masalah terkait materi 
relasi dan fungsi. Adapun representasi matematis yang akan diteliti ada tiga mengacu pada Villegas, Castro, dan Gutierrez (2009) yaitu representasi visual, verbal, dan simbol.

Subjek dalam penelitian ini adalah siswa kelas VIII C yang dipilih dengan teknik purposive sampling yaitu berdasarkan pertimbangan tertentu, pada penelitian ini yaitu berdasarkan tingkat kehadiran siswa dan wawancara dengan guru yang mengajar mata pelajaran matematika. Setelah mendapatkan subjek penelitian langkah selanjutnya yaitu siswa kelas VIII C diberikan tes kemampuan representasi matematis berupa soal essay. Selanjutnya dari hasil tes tersebut siswa dikategorikan ke dalam tiga kategori, yaitu kelompok siswa dengan kemampuan representasi matematis tinggi, sedang, dan rendah. Setelah dilakukan pengkategorian kemudian dipilih masing-masing 2 orang dari setiap kategori untuk dilakukan wawancara lebih lanjut. Penentuan Kategori Pengelompokan Subjek Penelitian berdasarkan Azwar (2012) dengan hasil tes pada tabel 1.

\begin{tabular}{cc}
\hline Interval & Kategori \\
\hline Skor $\geq 29,3$ & Tinggi \\
\hline $14,7 \leq$ Skor $\leq 29,3$ & Sedang \\
\hline Skor $<14,7$ & Rendah \\
\hline
\end{tabular}

Tabel 1. Penentuan Subjek Berdasarkan Hasil Tes

Teknik pengumpulan data yang digunakan adalah tes dan wawancara. Instrumen yang digunakan dalam penelitian ini adalah tes dan pedoman wawancara. Tes yang digunakan berupa tes kemampuan representasi matematis yang terdiri dari 3 soal tes materi relasi dan fungsi. Wawancara dilakukan dengan menanyakan rentetan pertanyaan untuk mendapatkan informasi lebih lanjut dari hasil tes siswa dan faktor yang penyebab siswa melakukan kesalahan. Indikator tes kemampuan representasi matematis yang digunakan merujuk pada Rangkuti (2013) dan Gaffar et al. (2019).

\begin{tabular}{|c|c|c|}
\hline No. & Jenis Representasi & Indikator \\
\hline 1 & $\begin{array}{l}\text { Representasi } \\
\text { Visual }\end{array}$ & $\begin{array}{l}\text { 1. Menyajikan kembali informasi yang diberikan ke dalam } \\
\text { bentuk gambar atau diagram. } \\
\text { 2. Membuat representasi visual menggunakan gambar atau } \\
\text { diagram untuk menyelesaikan masalah. }\end{array}$ \\
\hline 2 & $\begin{array}{l}\text { Verbal } \\
\text { (Kata-kata atau } \\
\text { teks tertulis) }\end{array}$ & $\begin{array}{l}\text { 1. Menyelesaikan masalah menggunakan kata-kata atau teks } \\
\text { tertulis } \\
\text { 2. Membuat representasi verbal untuk menjelaskan alasan } \\
\text { terhadap masalah yang diberikan } \\
\text { 3. Membuat kesimpulan menggunakan kata-kata atau teks } \\
\text { tertulis dari representasi gambar atau diagram. }\end{array}$ \\
\hline 3 & $\begin{array}{l}\text { Simbolik } \\
\text { (Persamaan atau } \\
\text { ekspresi } \\
\text { matematis) }\end{array}$ & $\begin{array}{l}\text { 1. Membuat model matematika untuk memperjelas dan } \\
\text { menyelesaikan masalah } \\
\text { 2. Menggunakan model matematika untuk menyelesaikan } \\
\text { masalah. } \\
\text { 3. Menyelesaikan masalah matematika yang melibatkan } \\
\text { ekspresi matematika yang disertai langkah-langkah } \\
\text { penyelesaian. }\end{array}$ \\
\hline
\end{tabular}

Tabel 2. Indikator Kemampuan Representasi Matematis 
Sebelum instrumen tes dan wawancara digunakan terlebih dahulu dilakukan uji instrumen yaitu menggunakan koefisien validitas isi aiken's $\mathrm{V}$ yang didasarkan pada hasil penilaian panel ahli untuk mengetahui sejauh mana instrumen tersebut mewakili konstrak yang diukur (Azwar, 2012). Teknik analisis data yang digunakan pada penelitian ini adalah analisis data yang meliputi reduksi data, penyajian data, dan penarikan kesimpulan (Miles, 1994).

\section{HASIL DAN PEMBAHASAN}

Pengujian validitas instrumen tes kemampuan representasi matematis dan pedoman wawancara dilakukan oleh 2 orang dosen ahli FKIP Unram. Yang selanjutnya dianalisis dengan menggunakan validitas Aiken V. Hasil analisis yang didapatkan untuk instrumen tes masuk kategori valid layak digunakan sesuai kriteria. Sedangkan untuk pedoman wawancara termasuk dalam kategori valid dan layak digunakan sesuai kriteria.

Data yang diperoleh dalam penelitian ini berupa hasil tes kemampuan representasi matematis dan wawancara dari siswa. Tes diberikan di kelas VIII C, sebanyak 30 siswa mengikuti tes. Selanjutnya siswa dikelompokkan ke dalam tiga kategori yaitu kategori kemampuan representasi matematis tinggi, sedang, dan rendah. Dari hasil tes ada 6 siswa termasuk dalam kategori kemampuan representasi matematis tinggi, 11 siswa dalam kategori kemampuan representasi matematis sedang, dan 13 siswa dalam kategori kemampuan representasi matematis rendah. Selanjutnya, dari setiap pengkategorian dipilih masing-masing 2 orang siswa untuk mewakili tiap kategori untuk dilakukan wawancara lebih lanjut.

\section{Kemampuan Representasi Matematis Tinggi}

Hasil tes dan wawancara kemampuan representasi matematis pada siswa kategori kemampuan representasi matematis tinggi.

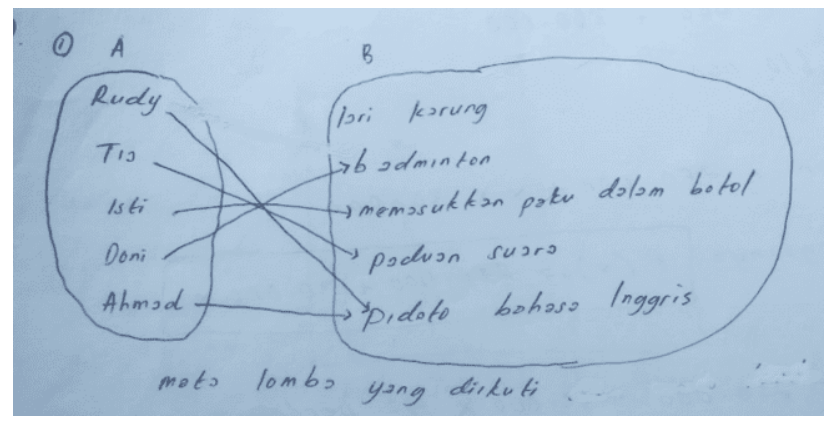

Gambar 1. Hasil Pekerjaan Representasi Gambar

Pada Gambar 1. dapat dilihat siswa dengan kemampuan representasi matematis tinggi mampu menggambar diagram panah dengan baik dan benar berdasarkan relasinya dan dari hasil wawancara siswa mampu menjelaskan diagram yang digambar dengan baik dan benar. 


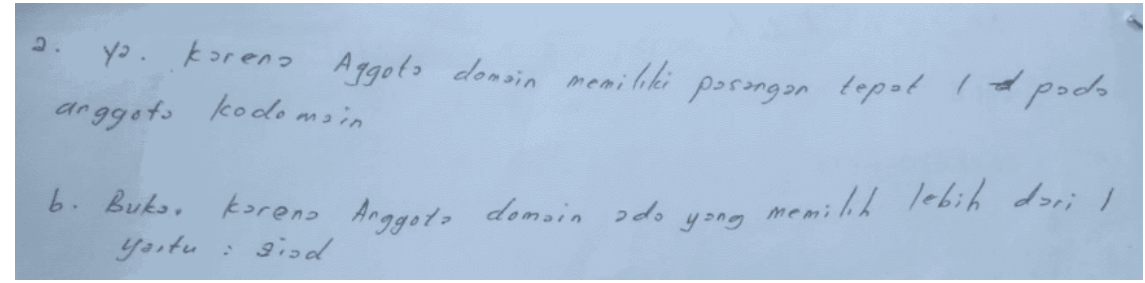

Gambar 2. Hasil Pekerjaan Soal Representasi Verbal

Hasil tes dapat dilihat pada Gambar 2. bahwa siswa dengan kemampuan representasi matematis tinggi mampu menuliskan alasan terkait konsep fungsi dan bukan fungsi secara benar dan logis dari beberapa diagram panah yang diberikan meskipun kata-kata yang digunakan masih kurang tepat. Dari hasil wawancara siswa mampu menjelaskan maksud jawabannya dengan baik.

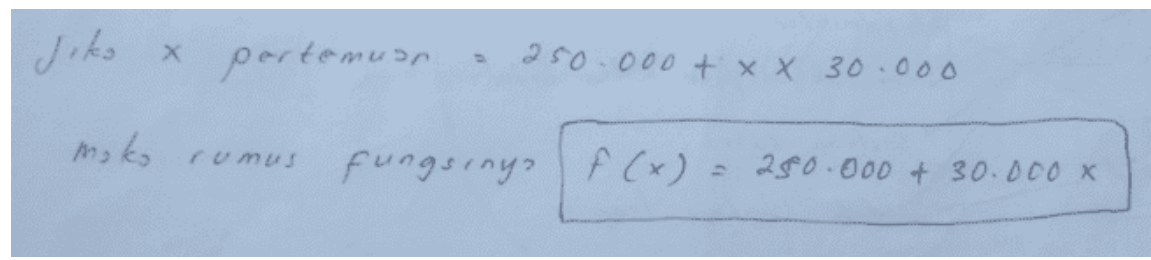

Gambar 3. Hasil Pekerjaan Soal Representasi Simbol

Dari Gambar 3. siswa dengan kemampuan representasi matematis tinggi mampu menentukan model matematika dengan benar beserta langkah-langkahnya dari permasalahan yang diberikan, siswa mampu menggunakan model matematika tersebut untuk menyelesaikan masalah yang lain.

\section{Kemampuan Representasi Matematis Sedang}

Hasil tes dan wawancara kemampuan representasi matematis pada siswa dengan kemampuan representasi matematis sedang yaitu sebagai berikut.

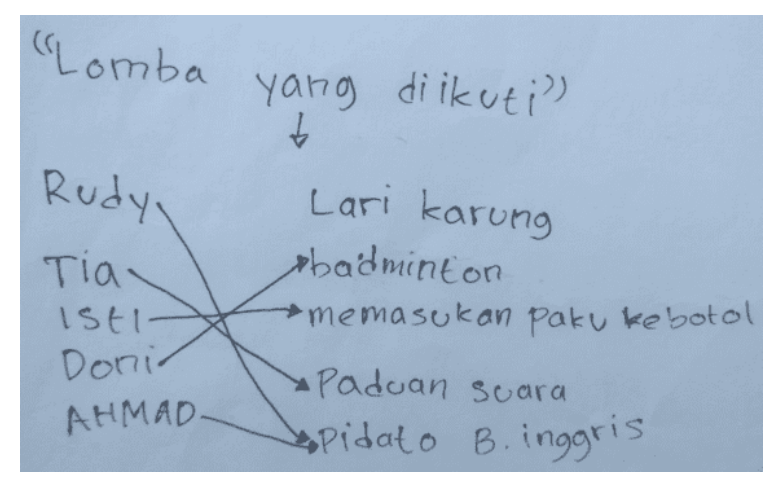

Gambar 4. Hasil pekerjaan representasi gambar

Dari Gambar 4. siswa dengan kemampuan representasi matematis sedang mampu memasangkan dua buah himpunan sesuai relasinya, akan tetapi siswa tidak menggambar diagram panah dengan benar, hal tersebut disebabkan karena siswa kurang teliti dalam menjawab soal. 


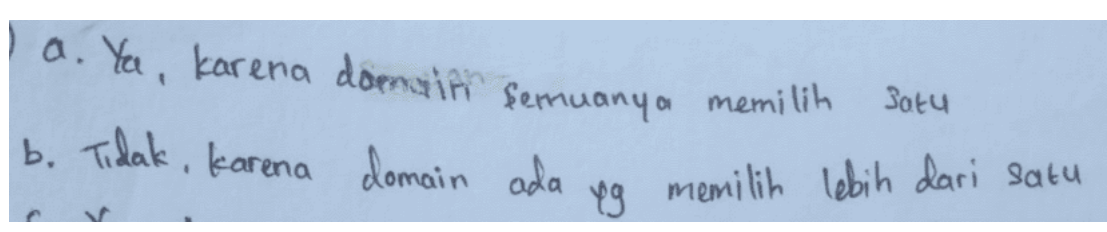

Gambar 5. Hasil Pekerjaan Representasi Verbal

Berdasarkan Gambar 5. siswa dengan kemampuan representasi matematis sedang sudah bisa membedakan fungsi dan bukan fungsi akan tetapi alasan yang dituliskan kurang lengkap, berdasarkan hasil wawancara siswa sudah memahami konsep fungsi dan bukan fungsi tetapi penjelasan yang diberikan masih kurang lengkap.

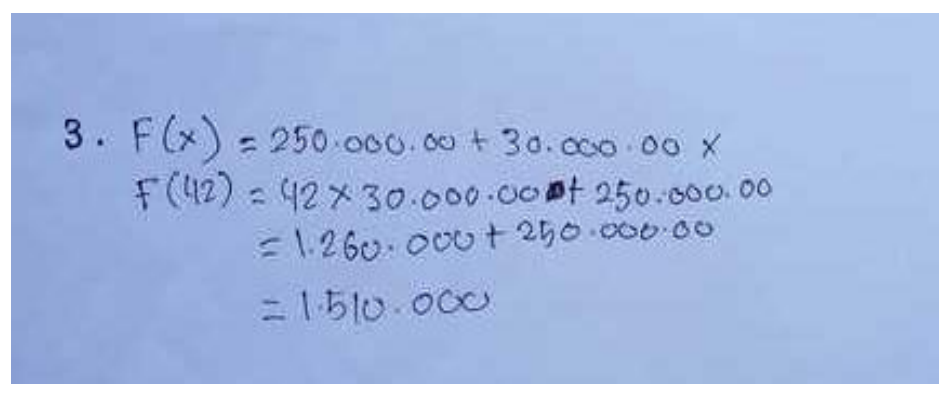

Gambar 6. Hasil Pekerjaan S4 Representasi Simbolik

Siswa dengan kemampuan representasi matematis sedang mampu membuat rumus fungsi dan menggunakan rumus fungsi untuk menyelesaikan permasalahan namun tidak disertai dengan langkahlangkahnya. Dari hasil wawancara siswa mampu menjelaskan jawabannya beserta langkah-langkahnya dengan benar.

\section{Kemampuan Representasi Matematis Rendah}

Hasil tes dan wawancara kemampuan representasi matematis pada siswa kategori kemampuan representasi matematis rendah sebagai berikut.

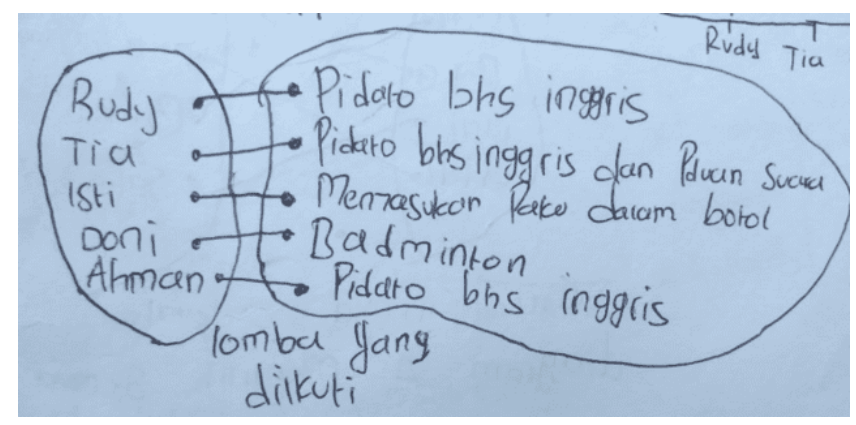

Gambar 7. Hasil Pekerjaan Representasi Visual

Dari Gambar 7. terlihat siswa dengan kemampuan representasi matematis rendah menyajikan gambar diagram panah akan tetapi masih kurang lengkap dan masih terdapat kesalahan, dimana siswa tidak memberikan arah panah antara dua himpunan tersebut serta cara memasangkan anggota himpunan 
dengan relasinya masih salah tidak sesuai dengan perintah soal. hal ini disebabkan kurangnya pemahaman terkait cara menggambar diagram panah dengan benar.

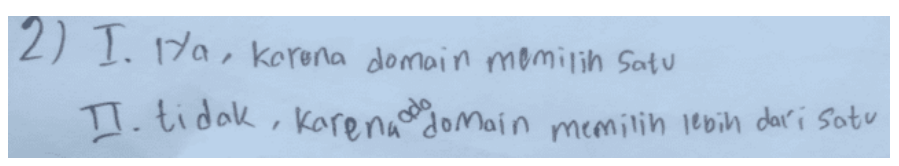

\section{Gambar 8. Hasil Pekerjaan Representasi Verbal}

Dari Gambar 8. siswa dengan kemampuan representasi matematis rendah menjawab dengan benar sesuai perintah soal akan tetapi alasan yang dituliskan masih kurang lengkap dan hanya sedikit dari penjelasan yang benar. Dari hasil wawancara siswa kurang memahami konsep fungsi dan bukan fungsi sehingga menyebabkan masih kesulitan dalam menuliskan alasan yang tepat secara tertulis.

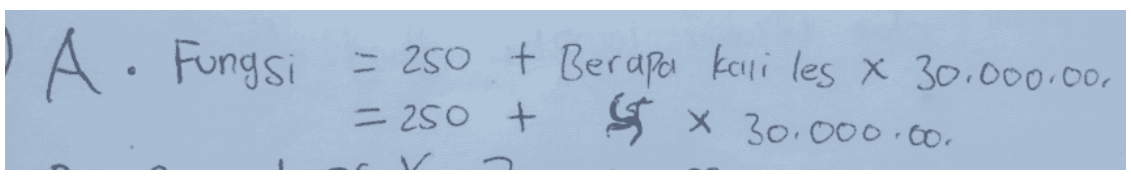

Gambar 9. Hasil pekerjaan representasi simbolik

Dari Gambar 9. siswa dengan kemampuan representasi matematis rendah dalam menyelesaikan soal representasi simbol belum mampu menentukan rumus fungsi dengan benar serta penggunaan simbol yang salah dan langkah-langkah ataupun perencanaan dalam mengerjakan soal tidak dituliskan. Dari hasil wawancara terlihat siswa tidak mampu menjelaskan secara detail langkah- langkah penyelesaiannya, siswa menjawab dengan singkat. Serta penjelasan dari siswa hanya sedikit yang benar.

\section{Deskripsi Kemampuan Representasi Matematis Tinggi}

Siswa dengan kategori kemampuan representasi matematis tinggi untuk indikator representasi gambar yaitu menyajikan kembali informasi yang diberikan ke dalam bentuk gambar atau diagram. Siswa dengan kemampuan representasi matematis tinggi tidak begitu kesulitan dalam mengerjakan soal representasi bentuk gambar atau diagram. siswa dengan kemampuan representasi matematis tinggi mampu menyajikan relasi dengan diagram panah dan diagram kartesius dengan tepat sesuai soal meskipun ada sedikit kesalahan pada keterangan atau cara penulisan yang kurang tepat dan siswa mampu menjelaskan hal tersebut pada saat dilakukan wawancara. Pada representasi visual hanya ada satu orang siswa yang menggambar diagram panah kurang lengkap yaitu pada keterangan nama himpunan tidak dituliskan dan tidak ada usecase diagram dari dua himpunan yang telah dibuat, hal ini disebabkan siswa kurang teliti ketika mengerjakan soal.

Siswa dengan kategori kemampuan representasi tinggi untuk indikator representasi verbal yaitu menyelesaikan masalah menggunakan kata-kata atau teks tertulis, Pada materi relasi dan fungsi siswa mampu menjelaskan alasan terkait konsep fungsi dan bukan fungsi pada masing-masing diagram secara benar dan logis meskipun pilihan kata yang digunakan masih kurang tepat. Pada saat dilakukan wawancara siswa mampu menjelaskan secara logis meskipun masih menggunakan bahasa yang kurang 
tepat. Ada tiga siswa dengan kemampuan representasi matematis tinggi tidak menjawab soal tentang ciri-ciri fungsi.

Siswa dengan kemampuan representasi matematis tinggi untuk indikator representasi simbol yaitu membuat model matematika untuk menyelesaikan masalah. Siswa dengan kemampuan representasi matematis tinggi sudah mampu membuat model matematika dengan benar dari permasalahan yang diberikan secara lengkap dan sistematis. Siswa dengan kategori tinggi mampu menggunakan model matematika untuk menyelesaikan masalah yang lain. Hal ini sejalan dengan hasil penelitian Lutfhi dan Khusna (2021) pada representasi simbolik yakni yang melibatkan ekspresi matematis dalam menyelesaikan masalah. Siswa dengan kemampuan representasi matematis tinggi mampu menggunakan model matematika untuk menyelesaikan masalah siswa menggunakan rumus yang benar serta proses pengerjaannya benar. Akan tetapi masih ada dua siswa dengan kemampuan representasi matematis tinggi yang tidak menyertakan langkah-langkah dalam menyelesaikan soal representasi simbolik.

\section{Deskripsi Kemampuan Representasi Matematis Sedang}

Siswa dengan kemampuan representasi matematis sedang untuk indikator representasi gambar yaitu menyajikan kembali informasi yang diberikan ke dalam bentuk gambar atau diagram, Siswa dengan kemampuan representasi sedang mampu menyelesaikan masalah yang diberikan menggunakan representasi visual namun kurang lengkap. Siswa dengan kemampuan representasi matematis sedang menyajikan relasi menggunakan diagram panah akan tetapi siswa tidak membuat usecase untuk masingmasing himpunan, ada lima siswa dengan kemampuan representasi matematis sedang yang tidak membuat usecase pada diagram panah dan Sembilan siswa yang tidak menuliskan judul sumbu tegak dan sumbu datar pada diagram kartesius. Hal ini sesuai dengan hasil yang didapatkan Herlina, Yusmin, dan Nursanganji (2017) bahwa kemampuan representasi visual siswa termasuk dalam kategori sedang dengan rata-rata skor yaitu 15,8 atau 43,89\%, siswa dapat menyajikan data dalam bentuk visual namun belum tepat yaitu masih terdapat kesalahan penulisan sajian visual. Akan tetapi pada saat dilakukan wawancara siswa mampu menjelaskan hal tersebut dengan benar.

Siswa dengan kemampuan representasi matematis sedang mampu menggunakan representasi verbal untuk menjelaskan alasannya terhadap masalah yang diberikan akan tetapi siswa masih salah dalam menuliskan alasannya dengan Bahasa yang tepat. Ada delapan siswa dengan kemampuan representasi matematis sedang yang tidak menuliskan jawaban terkait ciri-ciri fungsi dan tiga siswa tidak menuliskan alasannya terkait konsep fungsi dan bukan fungsi. Hal ini sejalan dengan penelitian (Herlina et al. (2017) siswa kesulitan untuk menuliskan kata-kata yang logis karena siswa tidak terbiasa diberikan soal terkait penyelesaian masalah menggunakan kata-kata tertulis. Pada saat dilakukan wawancara, siswa mampu menjelaskan alasan meskipun penjelasannya masih kurang tepat.

Siswa dengan kemampuan representasi matematis sedang untuk indikator representasi simbol yaitu membuat model matematika untuk menyelesaikan masalah. siswa mampu membuat model matematika dengan benar namun tidak menuliskan langkah-langkah secara sistematis. Seperti yang 
dituliskan dari hasil penelitian Lutfhi dan Khusna (2021) siswa dengan kelompok tengah mampu untuk menyelesaikan soal dengan ekspresi matematis namun ditemukan kesalahan perhitungan diakhir jawaban. Hal ini ditunjukkan tidak semua siswa kategori kemampuan representasi matematis sedang mampu membuat model matematika dan menggunakan model matematika untuk menyelesaikan masalah, karena masih ada ditemukan lima siswa salah dalam membuat rumus fungsi dari permasalahan yang diberikan dan Ada empat siswa dengan kemampuan representasi matematis sedang tidak menuliskan langkah-langkah dalam menemukan rumus fungsi. Dari hasil wawancara siswa dengan kategori sedang mampu menjelaskan langkah-langkah dalam membuat model matematika serta menjelaskan perhitungannya dengan benar.

\section{Deskripsi Kemampuan Representasi Matematis Siswa Rendah}

Siswa dengan kemampuan representasi matematis rendah untuk indikator representasi gambar yaitu menyajikan kembali informasi yang diberikan ke dalam bentuk gambar atau diagram, siswa dengan kemampuan representasi matematis rendah mampu menyajikan relasi dengan diagram panah dan diagram kartesius serta menuliskan relasi menggunakan diagram panah sesuai perintah soal akan tetapi cara penulisannya masih salah. Berdasarkan hasil wawancara siswa dengan kemampuan representasi matematis rendah membuat gambar atau diagram sesukanya tanpa mengikuti aturan yang benar, ada tujuh siswa dengan kemampuan representasi matematis rendah yang tidak menuliskan jawabannya dengan diagram panah, enam siswa menuliskan diagram panah tetapi cara penulisan diagram panah masih salah dan tidak ada satu siswa yang mampu membuat diagram kartesius dengan benar.

Siswa dengan kemampuan representasi matematis rendah untuk indikator representasi verbal yaitu menyelesaikan masalah matematika dengan menggunakan kata-kata tertulis. Siswa belum mampu menggunakan kata-kata tertulis dalam memberikan alasan dari setiap diagram tersebut secara benar dan kata-kata yang digunakan tidak masuk akal. Ada satu siswa dengan kemampuan representasi matematis rendah yang tidak menuliskan alasannya terkait konsep fungsi dan dua belas siswa menuliskan alasannya tetapi alasan yang dituliskan masih salah. Siswa kesulitan untuk membuat kesimpulan menggunakan kata-kata, hanya satu siswa dengan kemampuan representasi matematis rendah yang mampu membuat kesimpulan terkait ciri-ciri fungsi dengan bahasa yang masuk akal. Hal ini sesuai dengan hasil penelitian Merliza (2020) kemampuan representasi verbal (kata atau teks tertulis), ratarata peserta didik telah cukup baik walaupun tidak keseluruhan siswa, karena masih ditemukan beberapa peserta didik kebingungan menjelaskan maksud dari gambar yang telah dibuat dan masih ditemukan peserta didik yang belum sanggup memberikan jawaban beserta penjelasan yang tepat karena kurangnya pemahaman tentang konsep fungsi. Ketika dilakukan wawancara, siswa belum mampu menjelaskan alasan dari jawabannya dengan kata-kata yang masuk akal.

Siswa dengan kemampuan representasi matematis rendah untuk indikator representasi simbol yaitu membuat model matematika untuk menyelesaikan masalah. Siswa dengan kemampuan representasi matematis rendah belum mampu membuat model matematika secara lengkap dan 
sistematis. Ada enam orang siswa dengan kemampuan representasi rendah yang hanya menuliskan jawaban akhir tanpa langkah-langkah dalam menemukan rumus fungsi, lima siswa menuliskan langkahlangkahnya tetapi solusi yang didapat masih salah dan hanya dua siswa yang menuliskan langkahlangkahnya dan mendapatkan solusi yang benar. Hal ini sejalan dengan penelitian Wijaya (2018) kemampuan representasi simbolik siswa yang berada dibawah KKM masih tergolong kurang baik dikarenakan siswa belum memahami konsep serta dalam penulisannya masih berantakan dan tidak tersusun secara urut dalam penyelesaian soal. Dari hasil wawancara, siswa belum memahami soal dan siswa terlihat kebingungan ketika menjelaskan jawabannya. Siswa juga kesulitan pada saat melakukan perhitungan.

\section{KESIMPULAN}

Berdasarkan hasil penelitian dan pembahasan, dapat disimpulkan siswa dengan kemampuan representasi tinggi telah mampu mencapai indikator kemampuan representasi matematis dengan sangat baik yaitu dengan persentase rata-rata skor $82,63 \%$. Siswa pada kategori sedang cukup mampu mencapai indikator kemampuan representasi matematis dengan persentase rata-rata skor kemampuan representasi matematis yaitu $51,26 \%$ berada pada kategori cukup. Siswa dengan kemampuan representasi matematis rendah kurang mampu mencapai indikator kemampuan representasi matematis yaitu dengan persentase rata-rata skor $25,95 \%$ berada pada kategori kurang.

\section{DAFTAR PUSTAKA}

Azwar, S. (2012). Penyusunan Skala Psikologi (2nd ed.). Yogyakarta: Pustaka Belajar.

Depdiknas. (2006). Peraturan Menteri Pendidikan Nasional Republik Indonesia Nomor 22 Tahun 2006 Tentang Standar Isi Satuan Pendidikan Dasar dan Menengah. Jakarta: Depdiknas.

Gaffar, A., Afriadi, A., \& Satriani, S. (2019). Analisis kemampuan representasi matematis siswa dalam menyelesaikan soal matematika materi komposisi fungsi dan invers kelas XI IPA SMAN 1 Gowa. Pedagogy, 4(1). https://doi.org/http://dx.doi.org/10.30605/pedagogy.v4i1.1456

Herlina, H., Yusmin, E., \& Nursanganji, A. (2017). Kemampuan representasi matematis siswa dalam materi fungsi di kelas VIII SMP Bumi Khatulistiwa. Jurnal Pendidikan Dan Pembelajaran UNTAN, 6(10), 1-9.

Huda, U., Musdi, E., \& Nari, N. (2019). Analisis kemampuan representasi matematis siswa dalam menyelesaikan soal pemecahan masalah matematika. Jurnal Ta'dib, 22(1), 19-25. https://doi.org/10.31958/jt.v22i1.1226

Hwang, W. Y., Chen, N. S., Dung, J. J., \& Yang, Y. L. (2007). Multiple representation skill and creativity effects on mathematical problem solving using a multimedia whiteboard system. Educational Technology \& Society, 10(2), 191-212.

Kalathil, R. R., \& Sherin, M. A. (2000). Role of students' representations in the mathematics classroom. Fourth International Conference Of The Learning Science, 7(3), 27-28. 
Lutfhi, J. S., \& Khusna, H. (2021). Analisis kemampuan representasi matematis siswa berdasarkan tingkat motivasi belajar pada pandemi covid-19. Jurnal Cendekia: Jurnal Pendidikan Matematika, 5(3), 2185-2197. https://doi.org/10.31004/cendekia.v5i3.728

Merliza, P. (2020). Kemampuan representasi matematis peserta didik pada materi relasi dan fungsi di kelas VIII B SMP Darul Ulum Sekampung. Math Educa Journal, 4(2), 144-156.

Miles, B. H. (1994). Qualitative Data Analysis A Methods Sourcebook (3rd ed.). USA: Library of Congress Cataloging In Publication Data.

NCTM. (2000). Principles and Standards for School Mathematics. Reston, VA: NCTM.

Rangkuti, A. N. (2013). Representasi matematis. Logaritma: Jurnal Ilmu-Ilmu Pendidikan Dan Sains, 1(2), 49-61. https://doi.org/https://doi.org/10.24952/paedagogik.v6i01.168

Sabirin, M. (2014). Representasi dalam pembelajaran matematika. JPM IAIN Antasari, 1(2), 33-44. https://doi.org/10.18592/jpm.v1i2.49

Sugiyono. (2013). Metode Penelitian Pendidikan Pendekatan Kuantitatif, Kualitatif, dan R\&D. Bandung: Alfabeta.

Villegas, J. L., Castro, E., \& Gutierrez, J. (2009). Representation in probling solving: a case study in optimization problem. Electronic Journal of Research in Educational Psychology, 7(1), 279-308.

Wijaya, C. B. (2018). Analisis kemampuan representasi matematis siswa dalam menyelesaikan soal lingkaran pada kelas VII-B Mts Assyafi'iyah Gondang. Suska Journal of Mathematics Education, 4(2), 115-124. https://doi.org/10.24014/sjme.v4i2.5234

How to cite : Iffa, D. S., Subarinah, Sri., Baidowi., \& Sripatmi., 2022. Kemampuan Representasi Matematis Siswa dalam Memecahkan Masalah Relasi dan Fungsi Kelas VIII SMP. Jurnal Riset Pendidikan Matematika Jakarta. 4(1). 1-11. https://doi.org/10.21009/jrpmj.v4i1.23021

To link to this article: https://doi.org/10.21009/jrpmj.v4i1.23021 